\title{
Recovery of functional groups and trophic relationships in tropical fisheries closures
}

\author{
Timothy R. McClanahan*
}

Wildlife Conservation Society, Marine Programs, Bronx, New York 10460, USA

\begin{abstract}
Ecological changes associated with Kenya's fisheries closures were examined using a space-for-time substitution chronosequence based on 5 fisheries closures that ranged in age since closure from 5 to $41 \mathrm{yr}$. The chronosequence allowed estimates of the rates of change and recovery of key ecological processes and functional groups. I asked if $\sim 35 \mathrm{yr}$ was sufficient time for the ecosystem to recover and stabilize from fishing effects. Total consumer biomass peaked at 15-20 yr, but the magnitude and time scale of other functional group responses varied and were not always predictable based on assumed successional rates of recovery (i.e. plants $>$ herbivore $>$ carnivore $>$ piscivore). For example, piscivore recovery was minor and variable while the biomass of herbivorous fishes was slow and had not clearly stabilized by the end of the time series. In contrast, predation rates on sea urchins were a key process that increased slowly and sea urchin biomass declined to very low levels at $\sim 20$ yr of closure. Against predictions, total herbivory estimates and fleshy erect algae and hard coral cover did not change with the age of the closures, indicating the importance of multiple types of herbivores and climate disturbances. For benthic cover groups, time since closure was a strong predictor $\left(\mathrm{R}^{2}>0.50\right)$ for seagrass and red coralline algae, which increased over time, and sand and calcareous green algae, which declined over time. These changes were complete on the 20 to $30 \mathrm{yr}$ time scale. Consequently, processes were generally slow and functional group recovery was not fully complete by $\sim 35 \mathrm{yr}$ of closure. I speculate that recovery processes and times in these closures are likely to be influenced by human disturbances in the surrounding seascape and that permanent, old, and large closures are needed to represent fully restored tropical reef lagoon ecosystems.
\end{abstract}

KEY WORDS: Alternate stable states $\cdot$ Fisheries management $\cdot$ Marine protected areas $\cdot$ Marine reserves · Phase shifts

\section{INTRODUCTION}

The studies of marine and fisheries ecologists indicate that marine fisheries resources are heavily exploited and frequently in need of reduced exploitation, recovery, and restoration (Worm et al. 2009). Consequently, in order to rebuild fisheries, managers need to know historical baselines and recovery times (Pitcher 2001). Marine fisheries closures are perceived as a primary tool for rebuilding these ecosystems (Roberts \& Polunin 1993) and meta-evaluations have indicated their potential for changing key aspects of reef ecology, such as population density, biomass, and numbers of species (Lester et al. 2009). Nevertheless, closure responses may represent a biomass response relative to the exploited baseline and socioeconomic context (Pollnac et al. 2010, Daw et al. 2011) rather than a return to a pristine or pre-human condition (McClanahan \& Omukoto 2011). Therefore, closures may be a response to different levels and time since fishing mortality - a novel portfolio of species and life histories that differ from both exploited and historical baselines (McClanahan \& Humphries 2012, Graham \& McClanahan 2013). The 
time to recovery for fish and ecosystem components in fisheries closures, to either an ecological equilibrium or a hypothetical or known historical condition, is not well-understood, and current recovery estimates vary greatly (Halpern \& Warner 2002, Russ \& Alcala 2004, Planes et al. 2005, McClanahan et al. 2007a, Aburto-Oropeza et al. 2011). A good estimate of recovery will also depend not just on the recovery of biomass or targeted fisheries species but also the stabilization of functional groups and processes influenced by indirect interactions or trophic cascades (Babcock et al. 2010).

Marine ecologists commonly describe novel ecosystems created by species or functional group interactions as trophic cascades, phase shifts, and alternate stable states (Pinnegar et al. 2000, Norström et al. 2009). A frequently described trophic relationship is the fishing-herbivorous fish-macroalgae-coral cascade where heavy fishing of herbivorous fishes results in increased macroalgae and a decline in coral cover (Bellwood et al. 2004, Mumby et al. 2006, Hughes et al. 2010). An additional cascade described for Kenya's fringing reefs is the fishing-triggerfish-sea urchinherbivorous fish-coralline algae cascade where fishing of triggerfish and herbivorous fish causes an increase in sea urchin numbers and a decline in red coralline algal cover (O'Leary \& McClanahan 2010). Studies on remote reefs with light fishing suggest that apex predators, such as sharks, can further influence these types of mid-to-low trophic level cascades (Houk \& Musburger 2013, Ruppert et al. 2013). The permanence, reversibility, and recovery times of these fishing-induced ecological cascades have been explored, but empirical data are sparse and mechanisms, causation, and interpretations of responses have been keenly debated (Dudgeon et al. 2010, Hughes et al. 2010). Regardless, the creation of fisheries closures is suggested as a practical way to prevent and reverse trophic cascades and to reduce macroalgae and restore coral cover (Bellwood et al. 2004, Mumby et al. 2006). Nevertheless, some experimental and long-term studies have found ecosystems to be resistant to change, very slow to reverse, or change to be context dependent (McClanahan et al. 2001, 2011b, Bellwood et al. 2006). Consequently, there is considerable need to evaluate how ecosystems respond to closures, the time scales of the change, and whether or not changes represent restored and historical baselines (Babcock et al. 2010, McClanahan \& Omukoto 2011, McClanahan \& Humphries 2012).

The study presented here evaluates aspects of these ecological changes in back reef lagoons by using a space-for-time substitution from Kenyan mar- ine protected areas, which represent among the oldest fully protected fisheries closures in the Indian Ocean (McClanahan et al. 2009a). A number of these closures have been studied for +20 yr between 1987 and 2009, which allowed for the creation of a $41 \mathrm{yr}$ time series from the initial protected area closures around 1968. Recovery of fish families has been studied and indicates family-specific and associated life history recovery responses (McClanahan et al. 2007a, McClanahan \& Humphries 2012). Here, I evaluate the fuller coral reef ecosystem focused on the main functional groups that are frequently discussed in the coral reef trophic cascade models: these include algae-coral-herbivorous fish-sea urchinspredators of macro- and micro-invertebrates, piscivores, and the ecological processes of herbivory and predation on sea urchins. The hypothesis that closures result in rapid recovery and stability (i.e. $<15 \mathrm{yr}$ ) of functional groups and ecological processes was tested.

\section{MATERIALS AND METHODS}

\section{Study sites and sampling design}

I collected data in 5 ecologically similar no-take back reef lagoon closures of which 4 were national marine parks (Malindi, Watamu, Mombasa, and Kisite MNP) and one an enforced community closure (Vipingo) and 3 were open access fished reefs (Fig. 1). I studied these reefs 18 times at approximately 1 to 3 yr intervals between 1987 and 2010, except Kisite, which was sampled 3 times. The number of sites per reef varied from 1 to 4 per sampling period. Therefore, the total replication as Site $\times$ Time varied by site for the full period of sampling (Table 1). The start of active management of no-take closures is difficult to estimate accurately. There are the legal gazettement dates, which are followed by a time when fishing was actually excluded, but this time varied from a few to as many as 5 yr. Nevertheless, the following years were used for the first year of closures: Malindi - 1968, Watamu - 1972, Kisite - 1973, Mombasa - 1991, and Vipingo - 2005.

The closure sizes varied from 0.4 to $28 \mathrm{~km}^{2}$ (Vipingo, $0.4 \mathrm{~km}^{2}$; Mombasa, $6 \mathrm{~km}^{2}$; Malindi and Watamu, $10 \mathrm{~km}^{2}$; and Kisite $28 \mathrm{~km}^{2}$ - but the actual area occupied by coral reef in Kisite is $<10 \mathrm{~km}^{2}$ ). Previous analyses of the effects of closure size found that it was either not important relative to socioeconomic variables in the surrounding areas (Daw et al. 2011) or not important above a closure size of $5 \mathrm{~km}^{2}$ 


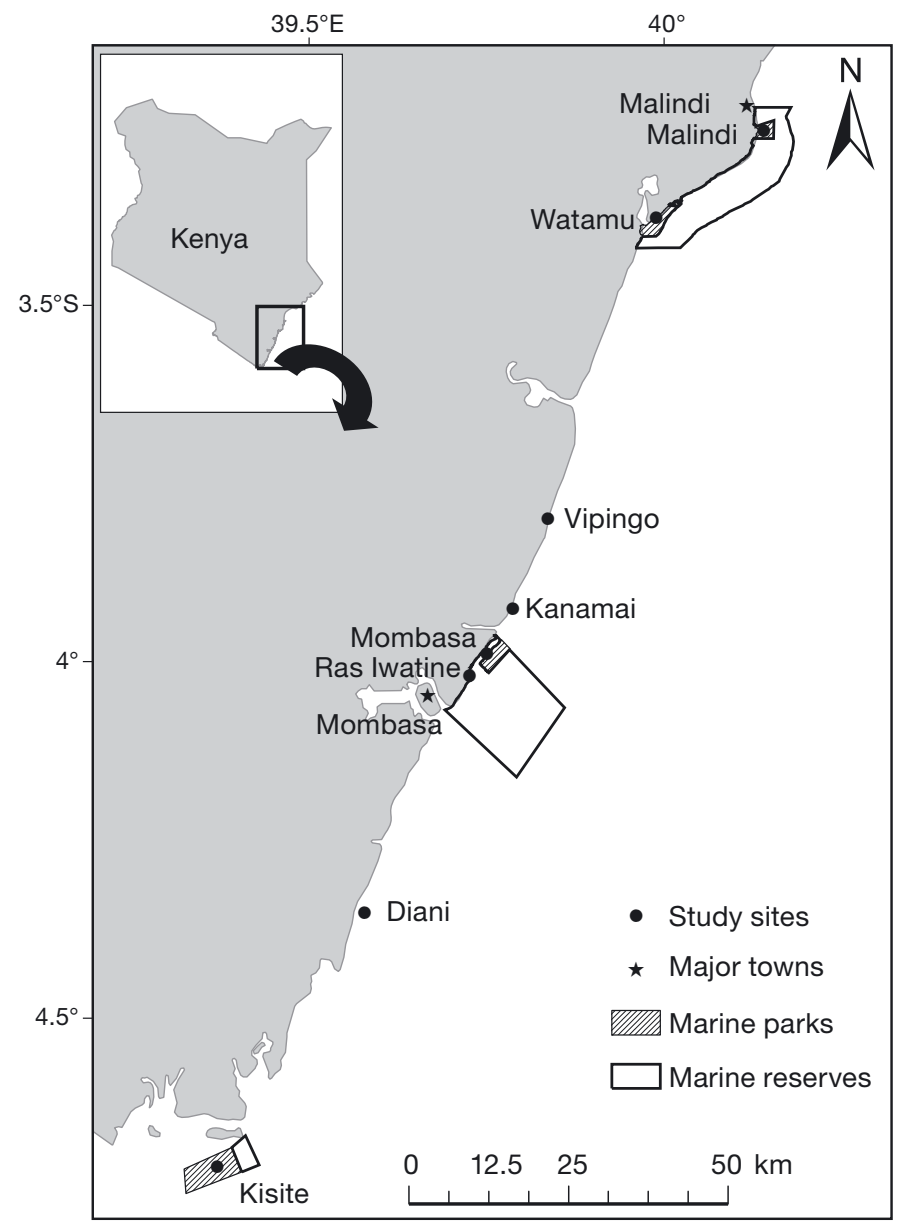

Fig. 1. Kenyan coastline and study sites. Marine parks and reserves are shown. A site at Vipingo has a community managed fisheries closure

(McClanahan et al. 2009a) and, therefore, not evaluated in this time-series evaluation. I sampled in shallow $(2$ to $5 \mathrm{~m}$ ) and calm back reef sites where the main substratum was living corals, coral rubble, sand, and seagrass and in the same locations as the benthic sampling. Habitat complexity and hard coral cover were similar between parks (McClanahan \& Graham 2005). The zero points for the chronosequence analyses were established by averaging the pooled data from 3 heavily fished reefs, Kanamai,
Ras Iwatine, and Diani. The assumption of site similarity was tested with the histories of these studied fished sites, which had no change in management, and this assumption was supported by a test of independence and residual model (McClanahan \& Humphries 2012).

\section{Field methods}

The study combined field data collected on benthic cover, fish biomass, and the relative predation rates on tethered sea urchins (McClanahan \& Muthiga 1989, McClanahan et al. 1994). Benthic cover estimates were based on a line-intercept method where, at each site, 9 to 12 10-m loosely draped line transects were haphazardly placed in the reef sites and all cover with lengths $>3 \mathrm{~cm}$ were measured to the nearest centimeter (McClanahan \& Shafir 1990). Data for these analyses were pooled into the functional groups of hard coral, soft coral, seagrass, turf, calcareous (Halimeda), crustose coralline, erect fleshy, sponge, and sand. Approximately, 14 sites were studied during each time period and $>1.1 \mathrm{~km}$ of line transect were completed in all sites combined and used to calculate the annual averages based on the years of closure.

The biomass of fish functional groups was estimated using underwater visual census of the numbers and sizes of fish in 23 fish families in replicate $5 \times 100 \mathrm{~m}$ belt transects (McClanahan et al. 2007b). All transects were completed by a single observer (T.R.M), and observer effects of this method have been studied and found to be small relative to the inherent variability in the reef community (McClanahan et al. 2007b). I conducted surveys during neap tides when the water level was between $\sim 2$ and $5 \mathrm{~m}$ deep. Individual fish were identified to family and their total lengths estimated and placed into $10 \mathrm{~cm}$ size intervals. Families included the Acanthuridae, Aulostomidae, Balistidae, Carangidae, Chaetodontidae, Diodontidae, Fistularidae, Haemulidae, Holocentridae, Labridae, Lethrinidae, Lutjanidae,

Table 1. Number of Site $\times$ Time replicates for the variables of substrate cover, fish surveys, and the sea urchin predation assays for the years sampled between 1987 and 2009

\begin{tabular}{|lcccccccc|}
\hline & $\begin{array}{c}\text { Diani } \\
\text { fished }\end{array}$ & $\begin{array}{c}\text { Kanamai } \\
\text { fished }\end{array}$ & $\begin{array}{c}\text { Kisite } \\
\text { unfished }\end{array}$ & $\begin{array}{c}\text { Malindi } \\
\text { unfished }\end{array}$ & $\begin{array}{c}\text { Mombasa } \\
\text { unfished }\end{array}$ & $\begin{array}{c}\text { Ras Iwatine } \\
\text { fished }\end{array}$ & $\begin{array}{c}\text { Vipingo } \\
\text { fished }\end{array}$ & $\begin{array}{c}\text { Watamu } \\
\text { unfished }\end{array}$ \\
\hline Substrate cover surveys & 39 & 42 & - & 39 & 42 & 18 & 41 & 20 \\
Fish surveys & 60 & 56 & 16 & 57 & 65 & 56 & 60 & 46 \\
Sea urchin predation assays & 39 & 42 & - & 38 & 42 & 18 & 41 & 19 \\
\hline
\end{tabular}


Muraenidae, Mullidae, Pempheridae, Penguipedidae, Pomacanthidae, Pomacentridae, Scaridae, Serranidae, Scorpaenidae, Siganidae, Sphyraenidae, and an 'others' category for individuals not in these families. I used the midpoint of the fish size classes to estimate the wet mass of each size class based on established length-weight relationships for each family and summed across all size classes to get a family wet weight estimate (McClanahan \& KaundaArara 1996). The sum of all size classes and families was used to estimate the total wet mass, and values were converted to a per hectare unit for comparison with other field studies. There were some changes in the numbers of the rare families sampled in some intervals, and these were accounted for by dividing the pooled undistinguished 'others' group by their proportion in subsequent more refined samples (McClanahan \& Humphries 2012). The others group was $0.21 \pm 0.08(\mathrm{SD})$ of the total sample when the fewest numbers of families was sampled, and therefore, when divided among the rare families, this represented a small proportion of the total sampled biomass.

For the purpose of the functional groups analysis and test of ecosystem function hypotheses, I pooled the wet weights of the families into functional groups of piscivores (Aulostomidae, Carangidae, Fistularidae, $40 \%$ of the Lutjanidae, Mullidae, Muraenidae, Pinquipedidae, Serranidae, Scorpaeinidae, Sphyraenidae), scavengers (Diodotidae, Haemulidae, Labridae $<30 \mathrm{~cm}$, Lethrinidae, $60 \%$ of Lutjanidae), sea urchin predators (Balistidae, Labridae $>30 \mathrm{~cm}$ ), herbivorous/detritivorous fishes (Acanthuridae, Scaridae, Siganidae), sponge eaters (Pomacanthidae), coral eaters (Chaetodontidae), and damselfishes (Pomacentridae). I acknowledge that there is some non-family level diet heterogeneity and the division between the Labridae and Lutjanidae is based on estimates of their diet changes or fraction of their diets but that this is a small part of the total biomass estimates and has a minor effect on final biomass values.

I estimated sea urchin biomass in each site by haphazardly tossing a stone tied to a rope, using the rope as the radius of a $10-\mathrm{m}^{2}$ plot and identifying sea urchins to the species and counting their numbers within this circular plot. I multiplied the speciesspecific density by a mean body weight from field measurements and summed across all taxa to estimate total sea urchin biomass (McClanahan 1998).

I calculated a consumption-based estimate of herbivory based on the assumption that herbivorous fish consumed the equivalent of $16 \%$ and sea urchins $1.6 \%$ of their body weight per day in plant matter, which is based on a summary of herbivory estimates used in a coral reef model (McClanahan 1995). I estimated the relative rates of predation on sea urchins by tethering 30 sea urchins with a hypodermic needle, returning $24 \mathrm{~h}$ later and recording the number of individuals dead from predation and using the average eaten as the time-specific estimate of predation. These methods have been evaluated and tested for habitat and management effects in previous publications (McClanahan \& Muthiga 1989, McClanahan et al. 1994, McClanahan 2000). Here, I present and statistically evaluate the full times series, which includes these initial data and the data collected after these publications.

\section{Data analyses}

With the site and time average data, I asked if there is evidence for leveling or stability in these functional groups and ecological processes over time by fitting 3 different realistic population or ecosystem-response models to the smoothed data. The sigmoid and exponential models are equations that level while the power model does not. Therefore, I considered greater fit to either of the 2 leveling models (exponential and sigmoid) by Akaike's information criteria (AIC) (Burnham \& Anderson 1998) and least-squares $\left(R^{2}\right)$ criteria as evidence for leveling. I considered a better fit to the power equations evidence for continued change. The early part of the time series is better sampled than the later part, and so the analysis is based on the first $36 \mathrm{yr}$ of the chronosequence in order to not overweight the model by the averages of more sparsely sampled later relative to younger dates. There was not sufficient overlap between sites in time to be able to test for site effects. Models with high coefficient of determination were fitted in $\mathrm{R}$ and the parameters presented and graphs of the best-fit equations produced in SigmaPlot.

\section{RESULTS}

Results are presented in a top-down order from consumers to ecological processes and benthic cover. Time since closure was a significant predictor for the total biomass and all fish group biomass except for coral eaters (Table 2a). Total biomass peaked at 15$20 \mathrm{yr}$ and was variable afterwards (Fig. 2). Piscivores and sponge eaters showed statistical significant but weak fits and only to the sigmoid equation, suggesting a leveling of biomass, but the weak fits preclude 
Table 2. Statistical fit of the ecological data to (F1) sigmoid, (F2) exponential, and (F3) power equation models. Best-fit models were compared for evidence of leveling or continued rise in the ecological response to cessation of fishing by the Akaike's information criterion (AIC) and $\mathrm{R}^{2}$ goodness-of-fit values. Ecological data are from sites organized along a space-for-time chronosequence, where the time since cessation of fishing ranged from 0 to $36 \mathrm{yr}$. Tests of fit included for (a) consumer trophic functional groups, (b) ecological processes, and (c) benthic cover functional groups. Equation parameters $a$ and $b$ for best-fit models given along with goodness-of-fit $\mathrm{AIC}$ and $\mathrm{R}^{2}$ and significant $\mathrm{p}$-values. Significance indicated by asterisks: ${ }^{*} \mathrm{p}<0.05,{ }^{* *} \mathrm{p}<0.01,{ }^{* * *} \mathrm{p}<0.001$

\begin{tabular}{|c|c|c|c|c|c|}
\hline Model & \multicolumn{3}{|c|}{ Equation } & \multicolumn{2}{|c|}{$\begin{array}{c}\text { Ecological } \\
\text { interpretations }\end{array}$} \\
\hline${ }^{\mathrm{F} 1}$ Sigmoid & \multicolumn{3}{|c|}{$f=\frac{a}{1+\mathrm{e}^{\left(x-x^{0}\right) / b}}$} & \multicolumn{2}{|c|}{ Leveling } \\
\hline${ }^{\mathrm{F}}$ Exponential & \multicolumn{3}{|c|}{$f=a\left(1-\mathrm{e}^{(-b x)}\right)$} & \multicolumn{2}{|c|}{ Leveling } \\
\hline \multirow[t]{2}{*}{${ }^{\mathrm{F} 3}$ Power } & \multicolumn{3}{|c|}{$f=a x^{b}$} & \multicolumn{2}{|c|}{ No leveling } \\
\hline & $a$ & $b$ & AIC & $\mathrm{R}^{2} \mathrm{p}$ & $\mathrm{p}$-value \\
\hline \multicolumn{6}{|l|}{ (a) Trophic groups } \\
\hline${ }^{\mathrm{F} 1}$ Piscivores & 7.86 & 5.16 & 179.43 & 0.206 & * \\
\hline${ }^{\mathrm{F}}$ Piscivores & 7.50 & -1.31 & 183.67 & 0.109 & 0.184 \\
\hline${ }^{\mathrm{F} 3}$ Piscivores & 3.73 & 0.22 & 187.50 & 0.096 & 0.239 \\
\hline${ }^{\mathrm{F} 1}$ Scavengers & 185.27 & 6.07 & 359.22 & 0.453 & $* * *$ \\
\hline${ }^{\mathrm{F}}$ Scavengers & 184.65 & -1.93 & 358.35 & 0.345 & $* * *$ \\
\hline${ }^{\mathrm{F} 3}$ Scavengers & 60.18 & 0.32 & 358.57 & 0.416 & $* * *$ \\
\hline $\begin{array}{l}{ }^{\mathrm{F}} \text { Sea urchin } \\
\text { predators }\end{array}$ & 26.11 & 3.89 & 280.21 & 0.277 & $*$ \\
\hline $\begin{array}{l}{ }^{\mathrm{F}} \text { Sea urchin } \\
\text { predators }\end{array}$ & 29.89 & -1.84 & 273.83 & 0.285 & $* * *$ \\
\hline $\begin{array}{l}\text { F3 Sea urchin } \\
\text { predators }\end{array}$ & -0.90 & 14.40 & 296.68 & 0.304 & $* *$ \\
\hline${ }^{\mathrm{F} 1}$ Sponge eaters & 19.18 & 32.44 & 242.20 & 0.177 & $*$ \\
\hline${ }^{\mathrm{F} 2}$ Sponge eaters & 17.31 & -0.56 & 244.90 & 0.077 & 0.258 \\
\hline${ }^{\mathrm{F} 3}$ Sponge eaters & 16.62 & 0.02 & 240.97 & 0.016 & 0.758 \\
\hline${ }^{\mathrm{F} 1}$ Corallivores & 14.21 & 0.67 & 233.20 & 0.084 & 0.229 \\
\hline${ }^{\mathrm{F} 2}$ Corallivores & 13.84 & 0.32 & 235.06 & 0.010 & 0.852 \\
\hline${ }^{\mathrm{F} 3}$ Corallivores & 10.03 & 0.13 & 236.24 & 0.059 & 0.378 \\
\hline${ }^{\mathrm{F} 1}$ Damselfish & 102.20 & 4.63 & 326.83 & 0.225 & $* *$ \\
\hline${ }^{\mathrm{F}}$ Damselfish & 111.32 & -2.52 & 328.75 & 0.270 & $* *$ \\
\hline${ }^{\mathrm{F} 3}$ Damselfish & 42.31 & 0.23 & 327.83 & 0.192 & $*$ \\
\hline${ }^{\mathrm{F}}$ Herbivorous fish & 558.46 & 9.41 & 410.87 & 0.684 & $* * *$ \\
\hline${ }^{\mathrm{F}}$ Herbivorous fish & 646.14 & -2.80 & 417.85 & 0.640 & $* * *$ \\
\hline${ }^{\mathrm{F}}$ Herbivorous fish & 79.01 & 0.57 & 409.55 & 0.690 & $* * *$ \\
\hline${ }^{\mathrm{F} 1}$ Sea urchins & 3661.19 & 10.92 & 522.43 & 0.840 & $* * *$ \\
\hline${ }^{\mathrm{F}}$ Sea urchins & 3507.89 & 11.72 & 522.12 & 0.850 & $* * *$ \\
\hline${ }^{\mathrm{F} 3}$ Sea urchins & 4544.64 & -0.63 & 540.64 & 0.670 & $* * *$ \\
\hline \multicolumn{6}{|c|}{ (b) Ecological processes } \\
\hline $\begin{array}{l}{ }^{\mathrm{F} 1} \text { Predation } \\
\text { on urchins }\end{array}$ & 0.89 & 2.41 & -64.70 & 0.772 & $* * *$ \\
\hline $\begin{array}{l}\text { F2 Predation } \\
\text { on urchins }\end{array}$ & 0.82 & -1.38 & -54.59 & 0.597 & $* * *$ \\
\hline $\begin{array}{l}\text { F3Predation } \\
\text { on urchins }\end{array}$ & 0.39 & 0.24 & -64.19 & 0.759 & $* * *$ \\
\hline
\end{tabular}

Table 2 (continued)

\begin{tabular}{|c|c|c|c|c|c|}
\hline & a & $b$ & AIC & $\mathrm{R}^{2}$ & $\mathrm{p}$-value \\
\hline $\begin{array}{l}{ }^{\mathrm{F} 1} \text { Consumption- } \\
\text { based herbivory }\end{array}$ & 84.48 & -1.49 & 318.66 & 0.098 & 0.165 \\
\hline $\begin{array}{l}{ }^{\mathrm{F} 2} \text { Consumption- } \\
\text { based herbivory }\end{array}$ & 87.78 & -1.07 & 324.65 & 0.118 & 0.127 \\
\hline $\begin{array}{l}{ }^{\mathrm{F} 3} \text { Consumption- } \\
\text { based herbivory }\end{array}$ & 54.61 & 0.13 & 322.51 & -0.062 & 0.134 \\
\hline \multicolumn{6}{|l|}{ (c) Benthic cover } \\
\hline${ }^{\mathrm{F} 1}$ Hard coral & 31.36 & 37.90 & 248.58 & 0.146 & 0.071 \\
\hline${ }^{\mathrm{F}}$ Hard coral & 28.93 & 1.10 & 239.82 & 0.001 & 0.978 \\
\hline${ }^{\mathrm{F} 3}$ Hard coral & 33.47 & -0.06 & 245.96 & 0.042 & 0.495 \\
\hline${ }^{\mathrm{F} 1}$ Macroalgae & 10.82 & 30.07 & 222.41 & 0.148 & 0.066 \\
\hline${ }^{\mathrm{F} 2}$ Macroalgae & 9.01 & -0.23 & 230.81 & 0.017 & 70.740 \\
\hline${ }^{\mathrm{F} 3}$ Macroalgae & 9.81 & -0.03 & 230.23 & 0.005 & 0.914 \\
\hline${ }^{\mathrm{F} 1}$ Coralline algae & 80.09 & 45.79 & 184.32 & 0.756 & $* * *$ \\
\hline${ }^{\mathrm{F} 2}$ Coralline algae & 97.28 & -5.02 & 190.40 & 0.684 & $* * *$ \\
\hline${ }^{\mathrm{F} 3}$ Coralline algae & 0.83 & 0.90 & 194.21 & 0.679 & $* * *$ \\
\hline${ }^{\mathrm{F} 1}$ Turf algae & 39.61 & -0.24 & 278.33 & 0.034 & 0.824 \\
\hline${ }^{\mathrm{F} 2}$ Turf algae & 37.71 & -0.01 & 246.78 & 0.100 & 0.180 \\
\hline${ }^{\mathrm{F} 3}$ Turf algae & 41.11 & -0.10 & 243.14 & 0.106 & 0.157 \\
\hline${ }^{\mathrm{F} 1}$ Seagrass & 4.33 & 12.50 & 211.34 & 0.693 & $* * *$ \\
\hline${ }^{\mathrm{F}}$ Seagrass & 2.47 & 0.06 & 201.92 & 0.740 & $* * *$ \\
\hline${ }^{\mathrm{F} 3}$ Seagrass & 0.07 & 1.65 & 223.02 & 0.528 & $* * *$ \\
\hline${ }^{\mathrm{F} 1}$ Soft coral & 4.32 & -0.22 & 112.88 & 0.021 & 0.634 \\
\hline${ }^{\mathrm{F}}$ Soft coral & 3.66 & -0.04 & 102.69 & 0.360 & $\quad * * *$ \\
\hline${ }^{\mathrm{F} 3}$ Soft coral & 4.87 & -0.36 & 93.84 & 0.519 & $* * *$ \\
\hline${ }^{\mathrm{F} 1}$ Sand & 11.91 & 26.51 & 175.27 & 0.661 & $* * *$ \\
\hline${ }^{\mathrm{F} 2}$ Sand & 13.96 & -0.03 & 186.98 & 0.510 & $* * *$ \\
\hline${ }^{\mathrm{F} 3}$ Sand & 15.21 & -0.24 & 199.00 & 0.305 & $* *$ \\
\hline${ }^{\mathrm{F} 1}$ Sponge & 1.06 & -1.11 & 80.52 & 0.023 & 30.678 \\
\hline${ }^{\mathrm{F} 2}$ Sponge & 0.57 & -0.09 & 82.21 & 0.001 & 0.982 \\
\hline${ }^{\mathrm{F} 3}$ Sponge & 1.05 & -0.33 & 41.63 & 0.148 & $3 \quad *$ \\
\hline${ }^{\mathrm{F} 1}$ Calcareous algae & 12.09 & 20.74 & 166.31 & 0.849 & $* * *$ \\
\hline${ }^{\mathrm{F} 2}$ Calcareous algae & 1.14 & 0.07 & 184.42 & 0.730 & $* * *$ \\
\hline${ }^{\mathrm{F} 3}$ Calcareous algae & 0.03 & 1.75 & 179.60 & 0.773 & $* * *$ \\
\hline
\end{tabular}

an estimate of the time scale of this leveling. Scavenger biomass fit well to all 3 models, and the 2 bestfits were to the sigmoid and exponential model, suggesting a leveling at 20-25 yr. Sea urchin predators increased over time, but there was considerable variability in the older closures that made it difficult to determine if their biomass leveled or not. Damselfish biomass reflected high variability, as well, but data fit best to the power equation, suggesting no leveling. Herbivorous/detritivorous fishes biomass had low scatter and fit well to all models but had a slightly better fit to the power equation, suggesting that they had not leveled by $36 \mathrm{yr}$. Sea urchin biomass fit equally well to the sigmoid and exponential equation, suggesting a rapid decline after 10-15 yr and leveling at low levels between 20-25 yr after closure (Fig. 3). 

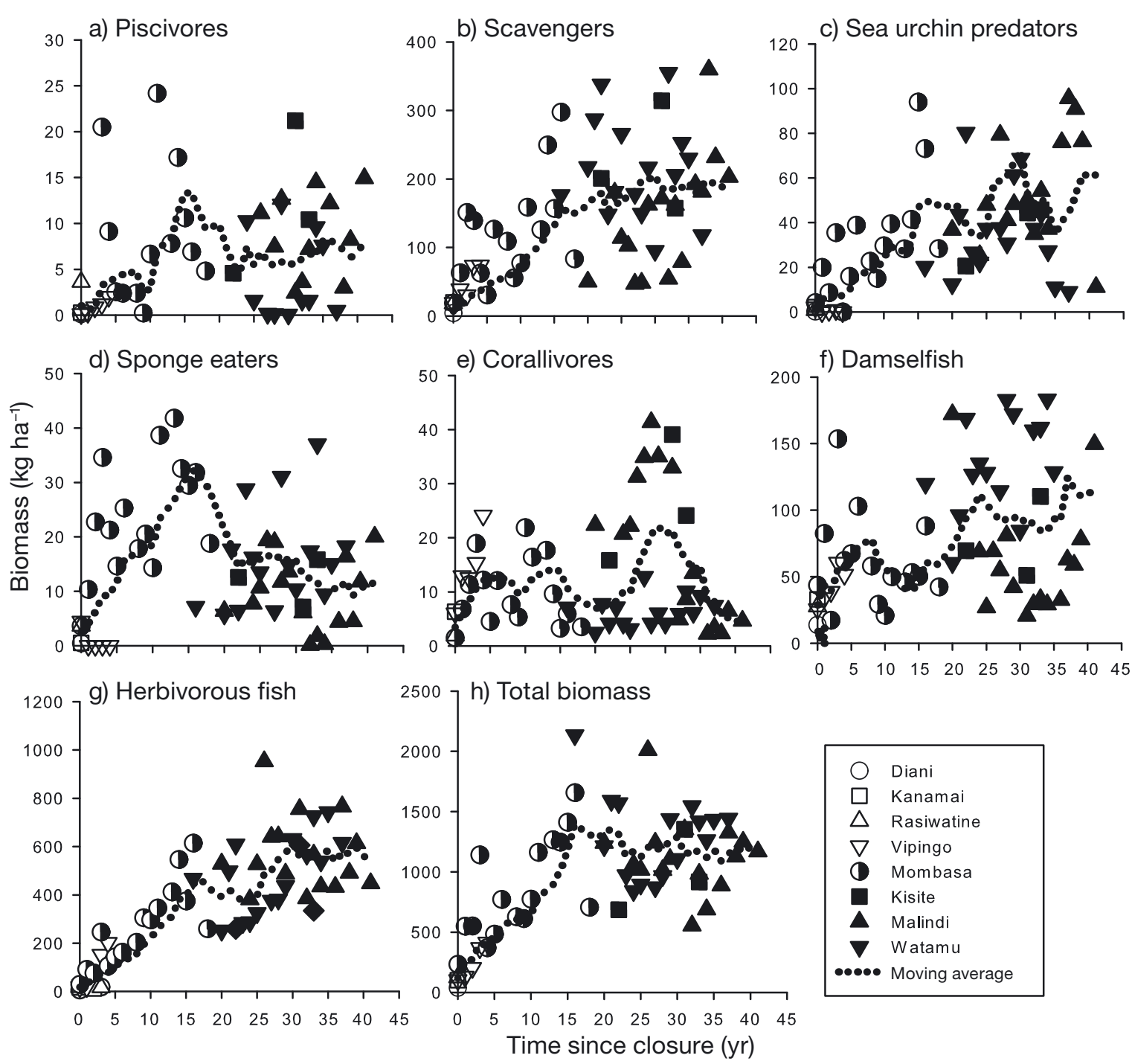

Fig. 2. Biomass of fish consumer functional groups on Kenyan coral reef as a function of time since their closure to fishing. The 5 yr running average is included; best-fit tests for the sites of ages 0 to 36 yr are presented in Table 2

Time since closure was a strong predictor for predation on sea urchins but not the consumption-based herbivory estimate (Table $2 \mathrm{~b}$ ). The herbivory estimate based on summed biomass of fish and sea urchin consumers indicate consumption rates of between 60 and $80 \mathrm{~kg} \mathrm{ha}^{-1} \mathrm{~d}^{-1}$ but not statistically significant with time. Relative predation on sea urchins fit well to all 3 models with nearly equal fit to the sigmoid and power model, which suggests insufficient data to distinguish between the leveling and rising models (Fig. 3b).

For benthic cover, time since closure was variable with strong, weak, and non-significant relationships (Table 2c). Hard coral, turf algae, and macroalgae cover showed no statistically significant relationships with time. Strong relationships $\left(R^{2}>0.50\right)$ were found for seagrass, sand, and green calcareous and red crustose coralline algae. Red crustose coralline algae increased strongly with time and a sigmoid equation fit best to the data, suggesting leveling by 36 yr. Seagrass cover also increased over time, and the exponential equation had the strongest fit, which suggests leveling. Conversely, sand cover declined and showed evidence for leveling at around $30 \mathrm{yr}$ after closure. Calcareous algae declined over time, and the best-fit equation was with the sigmoid model, suggesting leveling at around $20 \mathrm{yr}$. The weakest relationships were with sponge and soft corals that had high variation and declined over time without evidence for leveling (Fig. 4). 


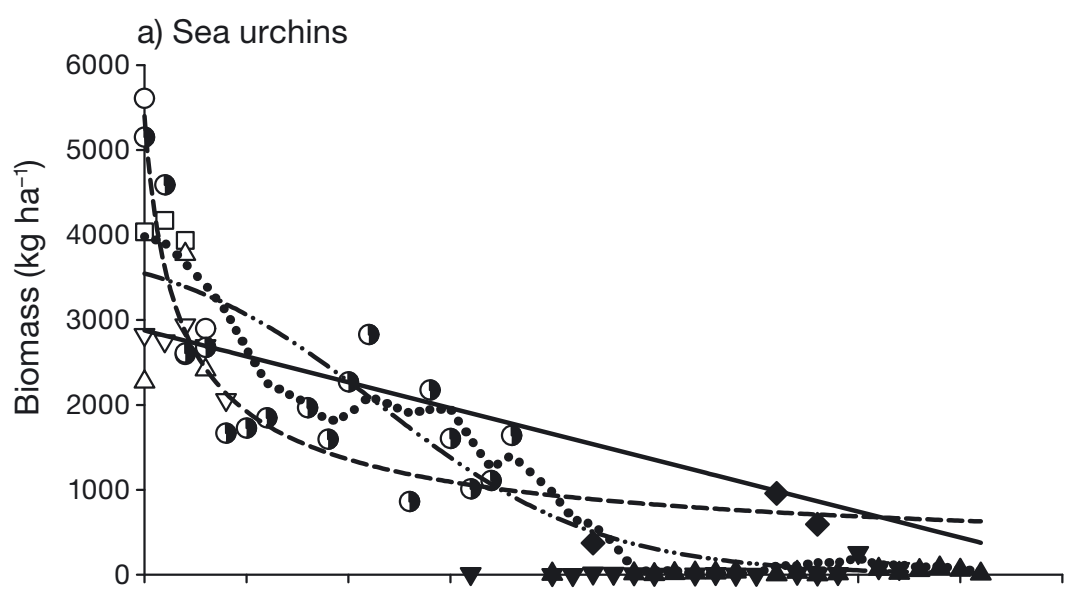

b) Sea urchin predation index

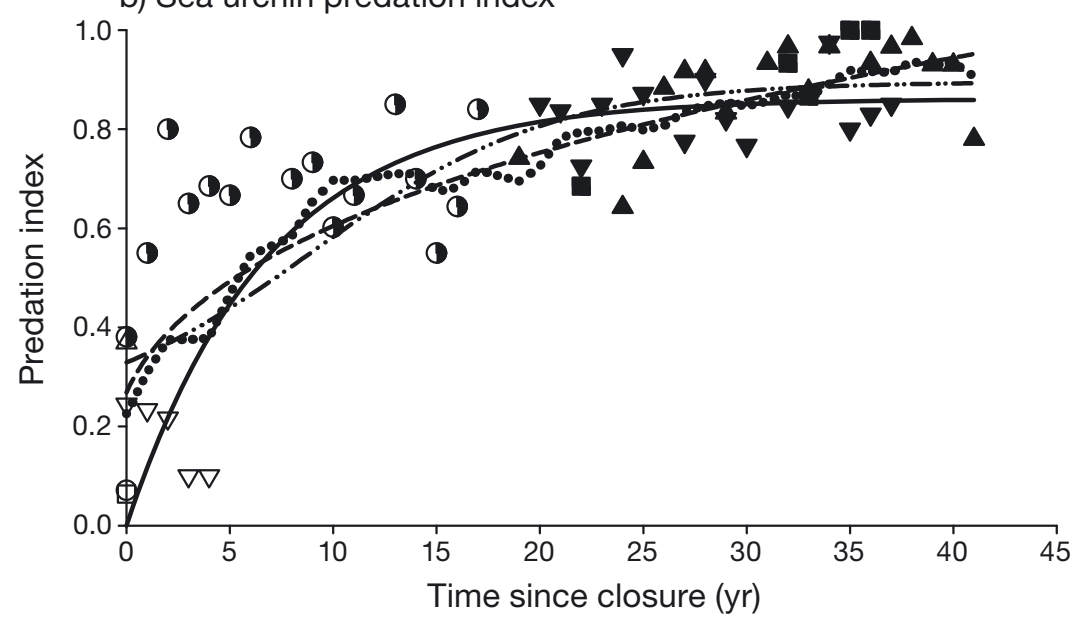

Fig. 3. (a) Biomass of sea urchins and (b) relative predation rates on tethered urchins as a function of the time since closure to fishing in Kenyan coral reefs. The 5 yr running average is included; best-fit tests for the sites of ages 0 to 36 yr are presented in Table 2. See legend in Fig. 2 for site symbols

dation on sea urchins and either an exponential or sigmoid decline in their biomass. Additionally, there was a slow rise in herbivorous fish, associated with an exponential increase in seagrass and a sigmoid increase in red coralline algal (O'Leary \& McClanahan 2010). These changes are among the key predictions of the Kenyan fringing reef lagoon trophic cascade model (McClanahan \& Shafir 1990, McClanahan 1995, Ruiz Sebastian \& McClanahan 2013). Less common benthic cover groups, including calcareous green algae, soft coral, sand, and sponge, declined over closure time and have not been considered as key components in the conceptual and simulations models. Changes were not fast and recovery rates were not clearly associated with the position of the functional group in the food web. Nonetheless, results suggest that human fishing impacts were the cause of the original ecological state and that removal of this impact resulted in slow recovery. The good fits of sigmoid relationships for predation and sea urchin biomass indicate the potential for some resistance followed by rapid change but no evidence for strong hysteresis (Dudgeon et al. 2010).

Predation rates on sea urchins were the most responsive process to the cessation of fishing, and while strongly

\section{DISCUSSION}

Time since closure was frequently a strong but also variable predictor for a number of fish groups, predation on and biomass of sea urchins, and a number of benthic cover components. Strong responses included biomass-dominant groups including recovery responses of scavenger and herbivorous fish, which are among the main fish functional groups targeted by fishing (Hicks \& McClanahan 2012). Sea urchin predators also increased as predicted, but they are cryptic and difficult to count, which produces high variability and made it difficult to conclude how much time is required for their full recovery. Consequently, the cessation of fishing resulted in a recovery of fish biomass over a period of about 15-20 yr, which was associated with a sigmoid increase in pre- predicted by time, it was slow. Further, distinguishing between the rising and leveling models of change was not possible but data suggest $>20 \mathrm{yr}$ for the full recovery of this process. Evaluations of sea urchin predators at a more resolved taxonomic level suggest that populations of the larger predatory wrasses level and decline at $<15$ yr after closure (McClanahan 2000, McClanahan et al. 2007a). Nevertheless, predation continues to rise due to the slower-recovery of triggerfish. Consequently, these results suggest that there are continuous communitylevel changes in the predators of macro-invertebrates many years after closure that reflect their growth and reproduction life history characteristics (McClanahan \& Humphries 2012). Sea urchins can play a role in maintaining herbivory when fishing reduces fish herbivores, but they also are expected to 


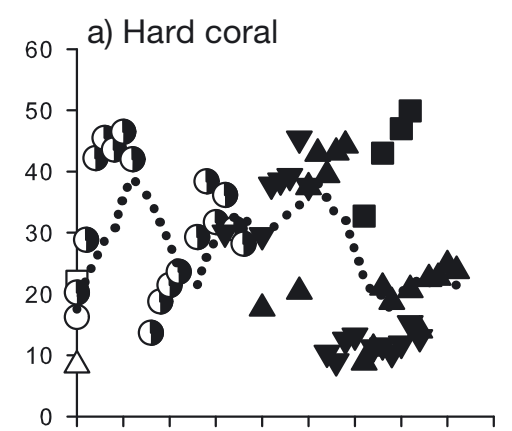

d) Algal turf
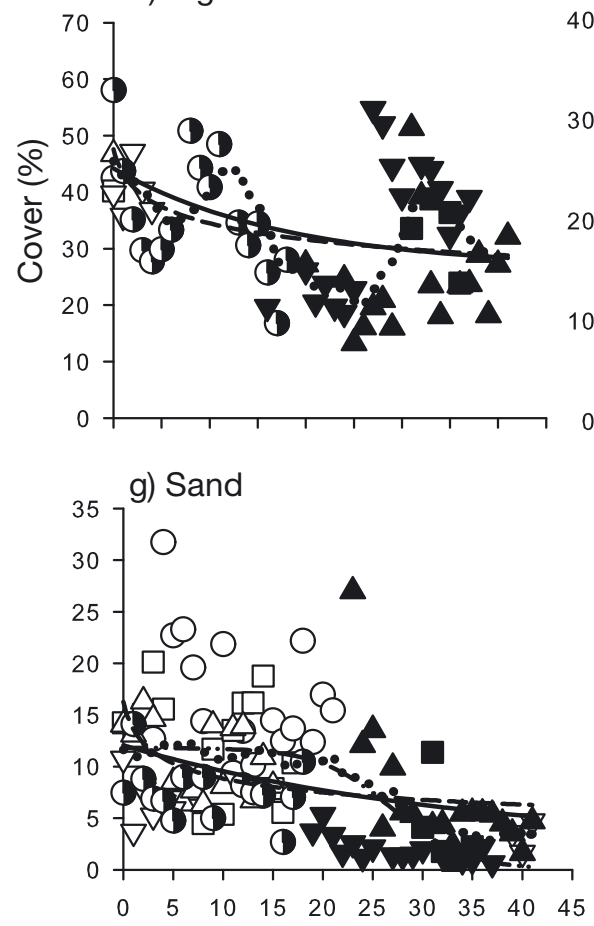

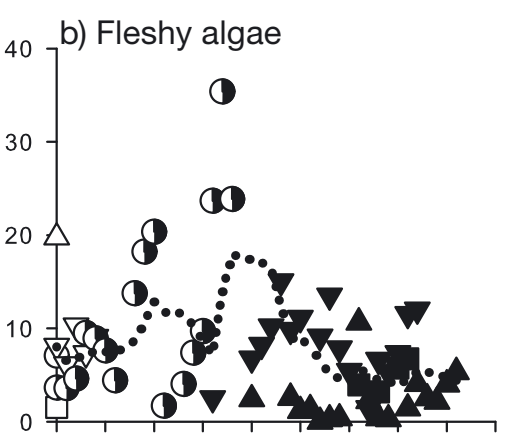

e) Seagrass

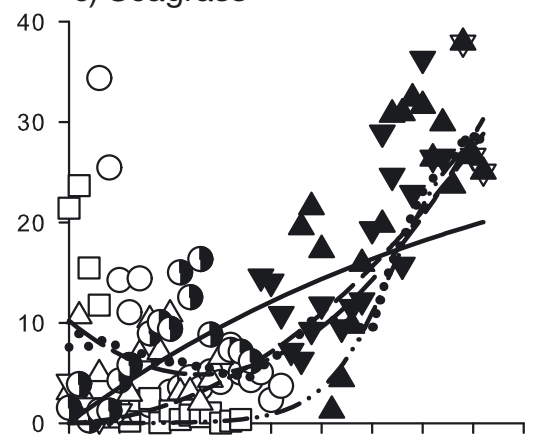

h) Sponge

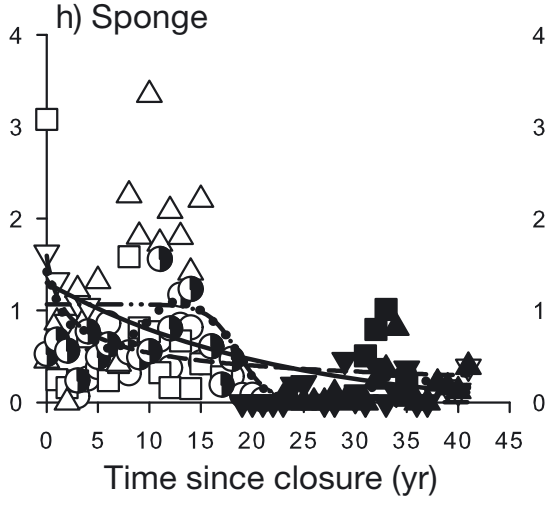

c) Coralline algae

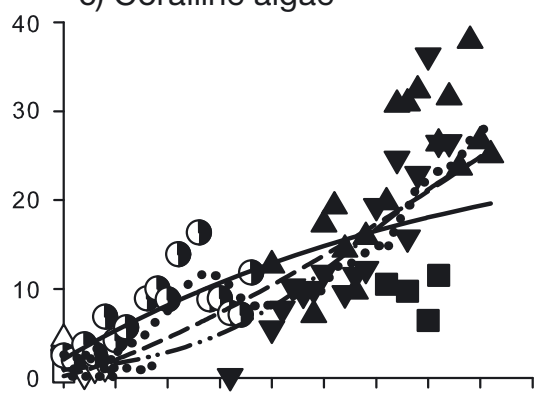

f) Soft coral
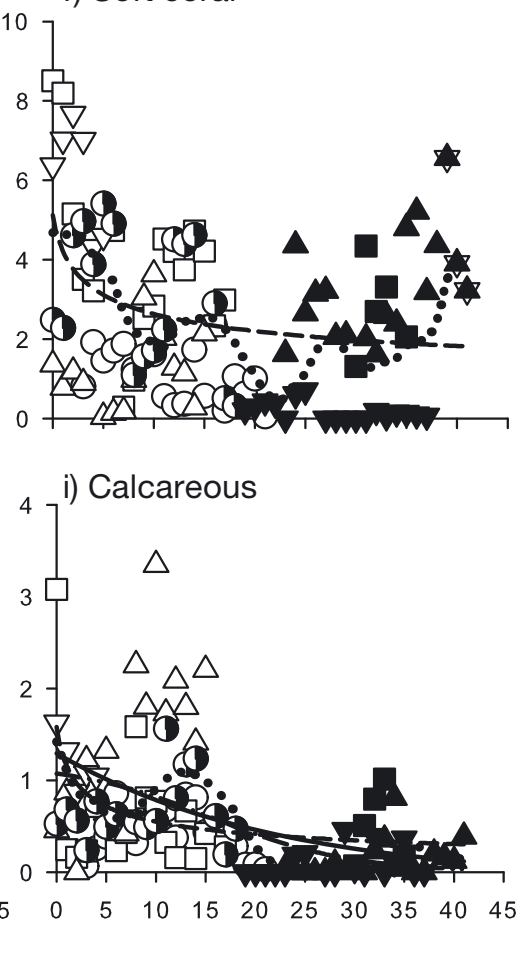

Fig. 4. Changes in benthic cover of major functional groups as a function of the time since closure to fishing in Kenyan coral reefs. The 5 yr running average is included; best-fit tests for the sites of ages 0 to 36 yr are presented in Table 2. See legend in

Fig. 2 for site symbols

compete with herbivorous fish for algae and influence the benthic composition and ecological processes, such as coral recruitment and net calcification (Carpenter 1986, O'Leary \& McClanahan 2010, O'Leary et al. 2012). Consequently, these interactions are important to reef processes, and simulation-modeling studies indicate that a reduction in sea urchins and rise of herbivorous fish is associated with an increase in reef calcification (Ruiz Sebastian \& McClanahan 2013).

The results are not supportive of the fishing-herbivorous fish-macroalgal-coral cascade model that was largely developed for Caribbean or other reefs where grazing sea urchins are uncommon (Mumby et al. 2006, Hughes et al. 2010). Reducing fishing impacts did not cause an increase in herbivory, reduce macroalgae, or increase coral cover (Nyström et al. 2000). In Kenya, the predation rates on sea urchins is a more critical process than herbivory because of the larger diversity of herbivores and the variable impact of fishing on these herbivores. Consequently, in Kenya's fringing reef, herbivory was fairly constant across the transitions from fishing to closures and suggests that predictions that fisheries closures will increase herbivory are likely to be region, ecosystem, or habitat specific (Bellwood et al. 2004, Hughes et al. 2010). Nevertheless, where sea urchins are common and abundant, the creation of fisheries 
closures could reduce herbivory during periods of recovery depending on the rates of recovery of herbivorous fishes relative to declines in sea urchins. Given that life history is a better predictor than a trophic succession model in the recovery of these reefs (McClanahan \& Humphries 2012), responses not predicted by a trophic succession concept are likely.

Possible explanations for the unresponsiveness of herbivory, coral cover, and erect fleshy algae to fisheries closures include the possibility that hard coral cover is more resilient to fisheries impacts than climate disturbances (Selig \& Bruno 2010, McClanahan et al. 2011a) and that fisheries closure are preferentially placed in areas where temperature histories increase their susceptibility to climate disturbances (Selig et al. 2012). The studied reefs were severely damaged by the 1998 thermal anomaly, and this contributed to some of the high coral and algal variability reported here and elsewhere (McClanahan 2008). The 1998 damage was greatest in fisheries closures due to more stable temperatures and more temperature-sensitive taxa in the closures (McClanahan 2008, McClanahan et al. 2009b), which may result from selectively in the placement of fisheries closure in many regions (Selig et al. 2012). Nevertheless, stochastic semi-parametric models initialized with the Kenyan benthic data did not find evidence for coral-algae biomodality or alternate stable state equilibriums in or out of fisheries closures (Żychaluk et al. 2012).

A meta-analysis of fisheries closures and climate disturbances found that it was only the oldest closures where closure management increased the resilience of coral to disturbances (Selig \& Bruno 2010). This same resilience response has also been argued for reefs within large marine wilderness areas (Sheppard et al. 2008) and could be associated with apex predator cascades where high shark numbers are also associated with higher herbivore numbers (Ruppert et al. 2013). In the Indian Ocean, there was greater mortality but also greater recovery of corals in closures (Ateweberhan et al. 2011). Studies in these Kenyan reef lagoons suggest climate disturbances change the taxonomic composition, life histories, and sizes of corals (McClanahan 2008, McClanahan et al. 2008, Darling et al. 2013), which suggests that the cover metric used here is a crude indicator of change. Consequently, while cover is the dominant metric of coral function, future evaluations of trophic cascades should consider the taxonomic and life history composition of benthic taxa and initial site and management effects of closures (Darling et al. 2010, 2013).
Erect fleshy or macroalgae were expected to decline with the age of closure, but this depends to a large extent on the abundance of unfished grazers, particularly sea urchins, which were abundant at our fished sites. Given that there were abundant sea urchin grazers and that these sites experienced a change in the types of grazers after closure, changes in taxonomic or functional group composition rather than changes in cover may be expected (McClanahan 2008). In fact, this study indicates a variety of changes in algal functional groups, some increasing and others declining with time since closure. Taxonomic studies of fleshy algae in Kenya suggest that sea urchin grazing differs from fish in their influence on the taxonomic composition, with smaller differences in total algal abundance (McClanahan 2008). The benthic cover results found here may not occur in coral reef regions and habitats where non-fisheries grazers, such as sea urchins, are not abundant (Lessios 1988, Mumby et al. 2006), which indicates the need for multiple or more inclusive models of coral reef cascades (McClanahan et al. 2002).

The above discussion assumes that the chronosequence methodology produces a realistic facsimile of long-term change over these coral reef sites. This is more likely if there is small to moderate spatial heterogeneity in the ecosystems and if they share similar types of disturbances apart from fisheries effects. These reefs were chosen for being similar back reef shallow lagoonal sites on a single fringing reef system where fishing is generally intense in the surrounding waters. There are some small to moderate differences among sites in terms of temperature variability and water quality (McClanahan et al. 2009b, Carreiro-Silva \& McClanahan 2012), which is expected to influence results at lower taxonomic levels more than the functional groups evaluated here. An evaluation of the fish communities in fished sites over $18 \mathrm{yr}$ indicated that fished sites were changing together (McClanahan \& Humphries 2012), which supports the contention of low between-site variability linked to similar habitat and environmental conditions.

These coral reefs are ecological islands of no fishing ( $~ 5 \%$ of the nearshore area) within a human and fishing-dominated seascape. The slow recovery reported here might be due to this island effect, and recovery times might be considerably shorter if disturbed sites were surrounded by more intact reef ecosystems (Planes et al. 2005). An expectation of this potential island effect is that the recently created closures would require more time to recover than older closures because of greater recent fishing dis- 
turbances in the seascape. If so, the broad-scale ecological conditions when the closures were started may influence recovery times (Daw et al. 2011). Regardless, the results suggest that permanent, old, and large closures are needed for establishing ecosystems representative of low human impacts, which are important for setting management goals (Pitcher 2001, Graham \& McClanahan 2013).

Acknowledgements. Grants from the Western Indian Ocean Marine Science Association, the Tiffany, McBean, and John D. and Catherine T. MacArthur Foundations to the Wildlife Conservation Society supported this work. Many people assisted with the benthic cover and ecological process assays over the long course of this field research and I am very grateful for this help. Thanks to Kenya's Office of the President for clearance to do research in Kenya and Kenya Wildlife Services for permission to work in the parks and Kiruwitu Community Organization for permission to work in their closure. A. Humphries, E. Mbaru, and C. Ruiz Sebastian assisted with statistics and graphs.

\section{LITERATURE CITED}

Aburto-Oropeza O, Erisman B, Galland GR, MascarenasOsorio I, Sala E, Ezcurra E (2011) Large recovery of fish biomass in a no-take marine reserve. PLoS ONE 6: e23601

Ateweberhan M, McClanahan TR, Graham NAJ, Sheppard C (2011) Episodic heterogeneous decline and recovery of coral cover in the Western Indian Ocean Coral Reefs 30: 739-752

> Babcock RC, Shears NT, Alcala AC, Barrett NS and others (2010) Decadal trends in marine reserves reveal differential rates of change in direct and indirect effects. Proc Natl Acad Sci USA 107:18256-18261

Bellwood DR, Hughes TP, Folke C, Nystrom M (2004) Confronting the coral reef crisis. Nature 429:827-833

Bellwood DR, Hughes TP, Hoey AS (2006) Sleeping functional group drives coral-reef recovery. Curr Biol 16: 2434-2439

Burnham KP, Anderson DR (1998) Model selection and multimodel inference: a practical information-theoretic approach. Springer, New York, NY

> Carpenter RC (1986) Partitioning herbivory and its effects on coral reef algal communities. Ecol Monogr 56:345-363

> Carreiro-Silva M, McClanahan TR (2012) Macrobioerosion of dead branching Porites, 4 to 6 years after mass coral mortality. Mar Ecol Prog Ser 458:103-122

> Darling ES, McClanahan TR, Cote IM (2010) Antagonistic interaction between bleaching and fishing on coral communities. Conserv Lett 3:122-130

$>$ Darling ES, McClanahan TR, Cote IM (2013) Life histories predict coral community disassembly under multiple stressors. Glob Change Biol 19:1930-1940

> Daw T, Cinner JE, McClanahan TR, Graham NAJ, Wilson SK (2011) Design factors and socioeconomic variables associated with ecological responses to fishery closures in the western Indian. Ocean Coast Manag 39:412-424

$>$ Dudgeon SR, Aronson RB, Bruno JF, Precht WF (2010) Phase shifts and stable states on coral reefs. Mar Ecol Prog Ser 413:201-216
Graham NAJ, McClanahan TR (2013) Last call for marine wilderness? Bioscience 63:395-402

Halpern BS, Warner RR (2002) Marine reserves have rapid and lasting effects. Ecol Lett 5:361-366

> Hicks CC, McClanahan TR (2012) Assessing gear modifications needed to optimize yields in a heavily exploited, multi-species, seagrass and coral reef fishes. PLoS ONE $7: \mathrm{e} 36022$

> Houk P, Musburger C (2013) Trophic interactions and ecological stability across coral reefs in the Marshall Islands. Mar Ecol Prog Ser 488:23-34

> Hughes TP, Graham NAJ, Jackson JBC, Mumby PJ, Steneck RS (2010) Rising to the challenge of sustaining coral reef resilience. Trends Ecol Evol 25:633-642

Lessios HA (1988) Mass mortality of Diadema antillarum in the Caribbean: what have we learned? Annu Rev Ecol Syst 19:371-393

> Lester SE, Halpern BS, Grorud-Colvert K, Lubchenco J and others (2009) Biological effects within no-take marine reserves: a global synthesis. Mar Ecol Prog Ser 384:33-46

McClanahan TR (1995) A coral reef ecosystem-fisheries model: impacts of fishing intensity and catch selection on reef structure and processes. Ecol Model 80:1-19

McClanahan TR (1998) Predation and the distribution and abundance of tropical sea urchin populations. J Exp Mar Biol Ecol 221:231-255

> McClanahan T (2000) Recovery of a coral reef keystone predator, Balistapus undulatus, in East African marine parks. Biol Conserv 94:191-198

> McClanahan TR (2008) Response of the coral reef benthos and herbivory to fishery closure management and the 1998 ENSO disturbance. Oecologia 155:169-177

> McClanahan T, Graham NAJ (2005) Recovery trajectories of coral reef fish assemblages within Kenyan marine protected areas. Mar Ecol Prog Ser 294:241-248

McClanahan TR, Humphries A (2012) Differential and slow life-history responses of fishes to coral reef closures. Mar Ecol Prog Ser 469:121-131

McClanahan TR, Kaunda-Arara B (1996) Fishery recovery in a coral-reef marine park and its effect on the adjacent fishery. Conserv Biol 10:1187-1199

McClanahan TR, Muthiga NA (1989) Patterns of predation on a sea urchin, Echinometra mathaei (de Blainville), on Kenyan coral reefs. J Exp Mar Biol Ecol 126:77-94

McClanahan TR, Omukoto JO (2011) Implications of modern versus historical fisheries catches for marine protected area goals. Conserv Biol 25:945-955

McClanahan TR, Shafir SH (1990) Causes and consequences of sea urchin abundance and diversity in Kenyan coral reef lagoons. Oecologia 83:362-370

> McClanahan TR, Nugues M, Mwachireya S (1994) Fish and sea urchin herbivory and competition in Kenyan coral reef lagoons: the role of reef management. J Exp Mar Biol Ecol 184:237-254

> McClanahan TR, McField M, Huitric M, Bergman K and others (2001) Responses of algae, corals and fish to the reduction of macroalgae in fished and unfished patch reefs of Glovers Reef Atoll, Belize. Coral Reefs 19:367-379

McClanahan TR, Polunin NVC, Done T (2002) Ecological states and the resilience of coral reefs. Conserv Ecol 6:18 (available at www.consecol.org/vol16/iss2/art18)

- McClanahan TR, Graham NAJ, Calnan JM, MacNeil MA (2007a) Toward pristine biomass: reef fish recovery in coral reef marine protected areas in Kenya. Ecol Appl 17: 1055-1067 
McClanahan TR, Graham NAJ, Maina J, Chabanet P, Bruggemann JH, Polunin N (2007b) Influence of instantaneous variation on estimates of coral reef fish populations and communities. Mar Ecol Prog Ser 340:221-234

McClanahan TR, Ateweberhan M, Omukoto J (2008) Longterm changes in coral colony size distributions on Kenyan reefs under different management regimes and across the 1998 bleaching event. Mar Biol 153:755-768

McClanahan TR, Graham NAJ, Wilson SK, Letourneur Y, Fisher R (2009a) Effects of fisheries closure size, age, and history of compliance on coral reef fish communities in the western Indian Ocean. Mar Ecol Prog Ser 396:99-109

McClanahan TR, Weil E, Maina J (2009b) Strong relationship between coral bleaching and growth anomalies in massive Porites. Glob Change Biol 15:1804-1816

McClanahan TR, Graham NAJ, MacNeil MA, Muthiga NA, Cinner JE, Bruggemann JH, Wilson SK (2011a) Critical thresholds and tangible targets for ecosystem-based management of coral reef fisheries. Proc Natl Acad Sci USA 108:17230-17233

McClanahan TR, Muthiga NA, Coleman RA (2011b) Testing for top-down control: Can post-disturbance fisheries closures reverse algal dominance? Aquat Conserv: Mar Freshw Ecosyt 21:658-675

> Mumby PJ, Dahlgren CP, Harborne AR, Kappel CV and others (2006) Fishing, trophic cascades, and the process of grazing on coral reefs. Science 311:98-101

Norström AV, Nyström M, Lokrantz J, Folke C (2009) Alternative states on coral reefs: beyond coral-macroalgal phase shifts. Mar Ecol Prog Ser 376:295-306

Nyström M, Folke C, Moberg F (2000) Coral reef disturbance and resilience in a human-dominated environment. Trends Ecol Evol 15:413-417

O'Leary JK, McClanahan T (2010) Trophic cascades result in large-scale coralline algae loss through differential grazer effects. Ecology 91:3584-3597

O'Leary JK, Braga JC, Potts DC, McClanahan TR (2012) Indirect consequences of fishing: reduction of coralline algae suppresses coral recruitment. Coral Reefs 31:547-559

Pinnegar JK, Polunin NVC, Francour P, Badalamenti F and others (2000) Trophic cascades in benthic marine ecosys-

Editorial responsibility: Janet Ley, St. Petersburg, Florida, USA tems: lessons for fisheries and protected-area management. Environ Conserv 27:179-200

Pitcher TJ (2001) Fisheries managed to rebuild ecosystems? Reconstructing the past to salvage the future. Ecol Appl 11:601-617

Planes S, Galzin R, Bablet JP, Sale PF (2005) Stability of coral reef fish assemblages impacted by nuclear tests. Ecology 86:2578-2585

Pollnac R, Christie P, Cinner JE, Dalton T and others (2010) Marine reserves as linked social-ecological systems. Proc Natl Acad Sci USA 107:18262-18265

Roberts CM, Polunin NVC (1993) Marine reserves: simple solutions to managing complex fisheries? Ambio 22: 363-368

Ruiz Sebastian C, McClanahan TR (2013) Description and validation of production processes in the coral reef ecosystem model CAFFEE (Coral-Algae-Fish-Fisheries Ecosystem Energetics) with a fisheries closure and climatic disturbance. Ecol Model 263:326-348

Ruppert JLW, Travers MJ, Smith LL, Fortin MJ, Meekan MG (2013) Caught in the middle: combined impacts of shark removal and coral loss on the fish communities of coral reefs. PLoS ONE 8:e74648

Russ GR, Alcala AC (2004) Marine reserves: long-term protection is required for full recovery of predatory fish populations. Oecologia 138:622-627

> Selig ER, Bruno JF (2010) A global analysis of the effectiveness of marine protected areas in preventing coral loss. PLoS ONE 5:e9278

> Selig ER, Casey KS, Bruno JF (2012) Temperature-driven coral decline: the role of marine protected areas. Glob Change Biol 18:1561-1570

> Sheppard CRC, Harris A, Sheppard ALS (2008) Archipelagowide coral recovery patterns since 1998 in the Chagos Archipelago, central Indian Ocean. Mar Ecol Prog Ser 362:109-117

Worm B, Hilborn R, Baum JK, Branch TA and others (2009) Rebuilding global fisheries. Science 325:578-585

Żychaluk K, Bruno JF, Clancy D, McClanahan TR, Spencer M (2012) Modelling regional coral-reef dynamics without mechanistic assumptions. Ecol Lett 15:151-158

Submitted: January 23, 2013; Accepted: October 11, 2013 Proofs received from author(s): January 13, 2014 